Research Article

\title{
Investigation of the Acoustic Properties of Chemically Impregnated Kayu Malam Wood Used for Musical Instrument
}

\author{
Md. Faruk Hossen (D), ${ }^{1,2}$ Sinin Hamdan, ${ }^{1}$ and Md. Rezaur Rahman' \\ ${ }^{1}$ Faculty of Engineering, Universiti Malaysia Sarawak, 94300 Kota Samarahan, Sarawak, Malaysia \\ ${ }^{2}$ Faculty of Science, University of Rajshahi, Rajshahi 6205, Bangladesh \\ Correspondence should be addressed to Md. Faruk Hossen; fhossen.chem@gmail.com
}

Received 12 October 2017; Accepted 22 November 2017; Published 29 April 2018

Academic Editor: Aniello Riccio

Copyright ( $) 2018$ Md. Faruk Hossen et al. This is an open access article distributed under the Creative Commons Attribution License, which permits unrestricted use, distribution, and reproduction in any medium, provided the original work is properly cited.

\begin{abstract}
The chemical modification or impregnation through preparing the wood polymer composites (WPCs) can effectively reduce the hygroscopicity as well as can improve the acoustic properties of wood. On the other hand, a small amount of nanoclay into the chemical mixture can further improve the different properties of the WPCs through the preparation of wood polymer nanocomposites (WPNCs). Kayu Malam wood species with styrene (St), vinyl acetate (VA), and montmorillonite (MMT) nanoclay were used for the preparation of WPNCs. The acoustic properties such as specific dynamic Young's modulus $\left(E_{d} / \gamma\right)$, internal friction $\left(Q^{-1}\right)$, and acoustic conversion efficiency (ACE) of wood were examined using free-free flexural vibration. It was observed that the chemically impregnated wood composite showed a higher value of $E_{d} / \gamma$ than raw wood and the nanoclay-loaded wood nanocomposite showed the highest value. The reverse trend was observed in the case of $Q^{-1}$. On the other hand, chemical impregnation has a minor effect on ACE of wood for musical instruments. The results suggested that the chemically impregnated Kayu Malam wood polymer nanocomposite (WPNC) is suitable for making soundboards of violin and guitar instruments to be played longer without losing tone quality.
\end{abstract}

\section{Introduction}

Currently, some selected traditional wood species have been selected for musical instruments by the musical instrument maker. Individual musical instruments require different acoustic properties for their optimal sound for soundboards, xylophone bars, and violin bows. The hygroscopic nature of wood affects the tone quality of wooden musical instruments. Spruce, rosewood, teak, and ebony are commonly used species due to their tight and uniform grain and high content of waxes/oils/resins that reduces the rate of moisture sorption [1]. The high-quality wood are getting harder to find and even more expensive. The musical instrument industry has looked for more available and less expensive wood species but continued to prefer the traditional ones. Although there are a lot of tropical wood species available in Malaysia, very few species such as Intsia palembanica (Merbau), Artocarpus champeden spreng (Cempedak),
Dialium species, and Agathis borneensis have been used for manufacturing traditional musical instrument such as sapeh, gendang, rebana, beduk, and $\operatorname{tar}[2,3]$. However the Kayu Malam wood species has not been selected by researchers for any musical purposes. Thus, in this research, the Kayu Malam wood collected from Sarawak, Malaysia, was selected to determine the acoustic properties for making musical instruments, and research is conducted dominantly based on trial and/or experience of manufacturer.

On the other hand, the hygroscopic nature of wood affects the tone quality of wooden musical instruments because as the moisture content increases, the acoustic properties of wood, such as the specific dynamic Young's modulus and internal friction $\left(Q^{-1}\right)$, are reduced or dulled $[4,5]$. In order to improve or stabilize the acoustic properties, varnish can be applied to the wooden parts or wood can be modified using chemical agents. It had been seen that 
TABLE 1: Different chemical agents used for preparation of wood polymer composites.

\begin{tabular}{|c|c|c|c|c|c|c|}
\hline Number & Wood & ST $(\mathrm{mL})$ & $\mathrm{VA}(\mathrm{mL})$ & $\mathrm{BPO}(\mathrm{gm})$ & MMT (gm) & Product \\
\hline 1 & & - & - & - & - & RW \\
\hline 2 & & 500 & - & - & - & WM1 \\
\hline 3 & Raw wood & 500 & 500 & - & - & WM2 \\
\hline 4 & & 500 & 500 & 20 & - & WPC \\
\hline 5 & & 500 & 500 & 20 & 20 & WPNC \\
\hline
\end{tabular}

excessive varnishing causes suppression of the sound level of the musical instruments [6]. The chemical modification or impregnation of wood can effectively reduce the hygroscopicity and increases dimensional stability of wood $[1,7]$. The polymerization technique has commonly been used to modify or impregnate the wood species through preparing the wood polymer composites (WPCs). In addition, small amount of nanoclay into the chemical mixture can further improve the different properties of the WPCs through the preparation of wood polymer nanocomposites (WPNCs) [8-10]. Thus, in this study, Kayu Malam wood species, styrene, vinyl acetate, and montmorillonite nanoclay were used for the preparation of WPNCs.

Therefore, the aim of this paper is to investigate the effect of chemical impregnation on the acoustic properties such as specific dynamic Young's modulus $\left(E_{d} / \gamma\right)$, internal friction $\left(Q^{-1}\right)$, and acoustic conversion efficiency (ACE) of prepared WPNCs and its suitability for making violin and guitar (acoustic instruments).

\section{Experimental}

2.1. Materials. Kayu Malam (Diospyros borneensis) wood species was collected from local forest of Sarawak, Malaysia. The chemicals used for specimens treatment were styrene (ST), vinyl acetate (VA), benzyl peroxide (BPO), and montmorillonite nanoclay (MMT 1.28E). All chemicals were analytical reagent grade and supplied by Merck, Germany.

2.2. Specimen Preparation. The sapwood portions of tree were cut into $120 \mathrm{~cm}$ length and $4 \mathrm{~cm}$ thickness. Then they were conditioned to air dry in a room with relative humidity of $60 \%$ and ambient temperature of $25^{\circ} \mathrm{C}$ for 3 months prior to testing. The clear, defect-free planks were machined into dimensions of $340 \mathrm{~mm}(L) \times 20 \mathrm{~mm}(T) \times 10 \mathrm{~mm}(R)$ for freefree vibration test.

2.3. Manufacturing of WPNC. Wood samples were preliminary dried in an oven at $105^{\circ} \mathrm{C}$ until constant weight before treatment, and dimensions and weight were measured. The dried samples were then placed in the impregnation chamber followed by the application of vacuum of $10 \mathrm{kPa}$ for $30 \mathrm{~min}$ in order to remove the air from the pores of the wood samples before addition of prepolymeric mixture. After that, vacuum was released. For the preparation of wood polymer composites (WPCs) and wood polymer nanocomposites (WPNCs), styrene, vinyl acetate,
MMT nanoclay, and BPO catalyst were added in different amounts according to Table 1 .

The samples were then kept in the chamber at room temperature for another $4 \mathrm{hrs}$ after attaining atmospheric pressure. After impregnation, samples were taken out from the chamber and excess impregnate from wood surfaces were wiped of. The samples were then wrapped with aluminium foil and cured for $24 \mathrm{hrs}$ at $90^{\circ} \mathrm{C}$ in an oven. Then it was followed by drying for $24 \mathrm{hrs}$ at $105^{\circ} \mathrm{C}$ for polymerization. Finally, the samples were then stored for acoustic measurements.

2.4. Fourier Transform Infrared (FTIR) Spectroscopy. The infrared spectra were recorded to determine the functional groups of wood samples. The Shimadzu 81001 FTIR spectrophotometer was used to scanned the sample with wavenumber at 4000 to $500 \mathrm{~cm}^{-1}$.

2.5. Scanning Electron Microscopy (SEM). The interfacial bonding between the wood cell wall and monomer mixture was examined using a scanning electron microscope (TM3030) supplied by JEOL Company Limited, Japan. The samples were coated with a thin layer of gold before viewing on the SEM, and the images were taken at a magnification of $500 x$.

2.6. Acoustic Measurements. The free-free flexural test was carried out according to the first mode of vibration [11]. The sample, metal plate, electromagnetic driver, and microphone were setup according to Figure 1. In order to achieve a resonant or natural frequency, the frequency was varied from $1 \mathrm{~Hz}$ to $1,000 \mathrm{~Hz}$, and dynamic Young's modulus $\left(E_{d}\right)$ was calculated using the following equation:

$$
E_{d}=\frac{4 \pi^{2} f^{2} l^{4} A \rho}{I\left(m_{n}\right)^{4}},
$$

where $I=b d^{3} / 12, d$ is the beam depth, $b$ is the beam width, $l$ is the beam length, $f$ is the natural frequency of the specimen, $n$ is the mode of vibration, $\rho$ is the density, $A$ is the cross-sectional area, and $m_{1}=4.73$.

The internal friction $\left(Q^{-1}\right)$ was obtained by reducing the amplitude to $0.5(6.02 \mathrm{~dB})$ below the amplitude of the resonant frequency using the following equation:

$$
Q^{-1}=\tan (\delta),
$$

where $\delta=\pi \Delta f / f_{0} \sqrt{3} ; \Delta f=f_{2}-f_{1} ; f_{0}=$ resonant frequency; $f_{1}=$ lower frequency; and $f_{2}=$ upper frequency. 


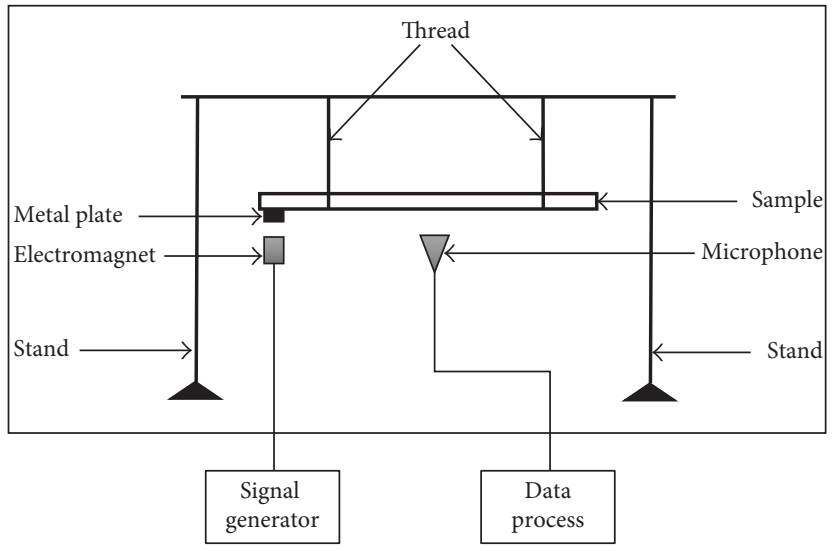

FIgURE 1: Schematic diagram for free-free flexural testing [11].

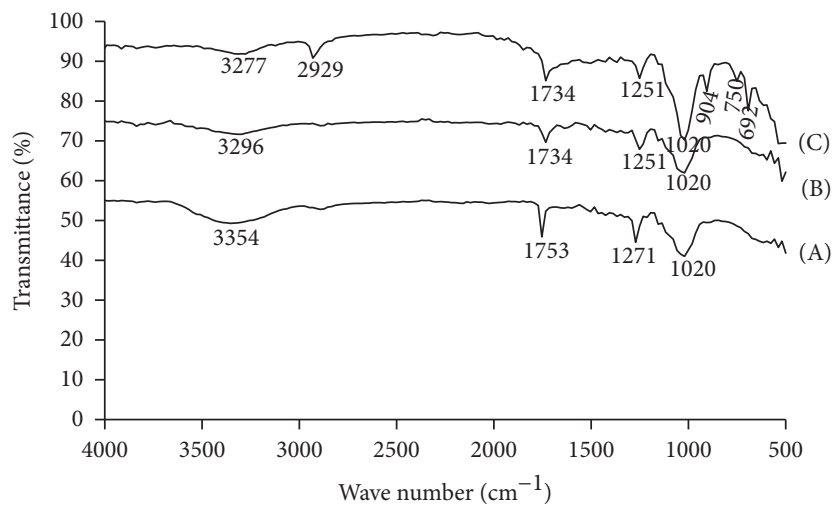

Figure 2: FTIR spectra for RW (A), WPC (B), and WPNC (C).

The acoustic converting efficiency (ACE) was calculated using the following equation:

$$
\mathrm{ACE}=\sqrt{\frac{E_{d} / \gamma}{\gamma \tan \delta}},
$$

where $\gamma=$ specific gravity $=m / m_{\mathrm{w}} ; m=$ the mass of sample at air-dried state; and $m_{\mathrm{w}}=$ the mass of displaced water.

\section{Results and Discussion}

3.1. FTIR Study. The FTIR spectra of raw wood (RW), wood polymer composite (WPC), and wood polymer nanocomposites (WPNCs) are shown in Figure 2. The absorption bands observed for raw wood (curve A) at $3,354 \mathrm{~cm}^{-1}, 1,753 \mathrm{~cm}^{-1}$, and $1,271 \mathrm{~cm}^{-1}$ correspond to $-\mathrm{OH}$ stretching of hydroxyl group in cellulose, $\mathrm{C}=\mathrm{O}$ stretching of acetylated xylem in hemicellulose, and $\mathrm{C}-\mathrm{O}$ stretching of acetyl group in lignin, respectively [12-14]. A decrease in the wave number to $3,296 \mathrm{~cm}^{-1}$ for $-\mathrm{OH}$ group was observed in WPC (curve B). The shifting of the corresponding peak to the lower wave numbers was probably due to the transfer of some hydroxyl groups from the wood cell walls to the polymer chains [15]. The other peaks also shifted toward lower wave numbers as the intensity decreased (curve B) due to polymerization. In the WPNC spectrum (curve C), the new peaks at $2,927 \mathrm{~cm}^{-1}$ and 904 to $692 \mathrm{~cm}^{-1}$ were observed along with the other peaks for MMT nanoclay. These peaks were assigned to aromatic symmetric $-\mathrm{CH}_{2}$ stretching and oxide bonds of metals into the MMT, respectively.

It was also observed that the intensity of -OH stretching decreased and shifted to $3,277 \mathrm{~cm}^{-1}$ compared to $3,354 \mathrm{~cm}^{-1}$ from RW $[16,17]$. The decrease in intensity and shifting of peaks to lower wave number might be due to the interaction of hydroxyl group of wood and clay with polymer which is reflected on acoustic properties shown in Figure 3 and also evident from SEM images in Figure 4. Similar decrease and shifting in intensities of $-\mathrm{OH}$ stretching to lower wave number had been reported by other researchers while studying the FTIR analysis of wood/polymer/clay nanocomposite [18].

3.2. Acoustic Properties. The acoustic properties of wood are expressed by three major properties such as specific dynamic Young's modulus $\left(E_{d} / \gamma\right)$, internal friction $\left(Q^{-1}\right)$, and acoustic converting efficiency (ACE). The first mode of vibration was considered to evaluate the acoustic properties using the freefree flexural vibration technique $[7,19] . E_{d} / \gamma$ and $Q^{-1}$ or $\tan \delta$ are related to sound velocity and sound absorption or damping within the wood, respectively, whereas the ACE is 


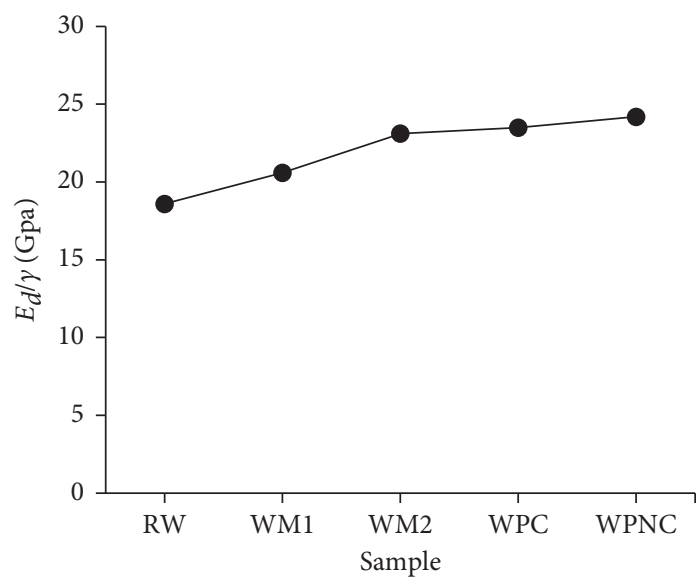

(a)

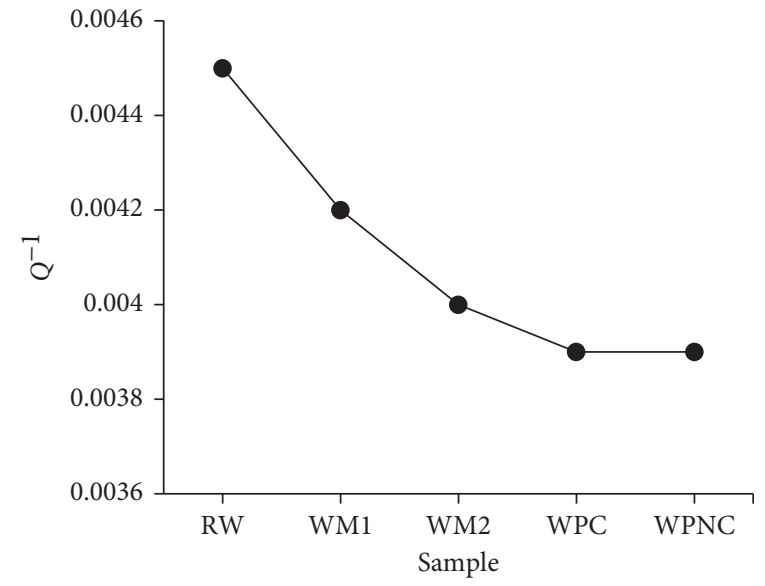

(b)

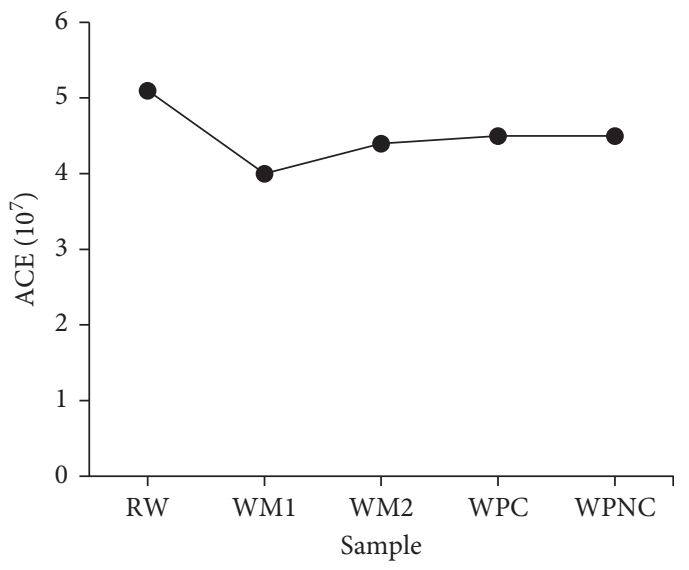

(c)

Figure 3: The specific dynamic Young's modulus $\left(E_{d} / \gamma\right)(\mathrm{a})$, internal friction $\left(Q^{-1}\right)(\mathrm{b})$, and acoustic converting efficiency (ACE) (c) of raw and polymerized Kayu Malam wood.

related to the ratio of acoustic energy radiated from the musical instrument to the energy given by the string [20]. In this study, the acoustic properties of raw and chemically impregnated (polymerized) Kayu Malam wood are shown in Figure 3. It was observed (Figure 3(a)) that the chemically impregnated wood (WM1, WM2, and WPC) showed a higher value of $E_{d} / \gamma$ than RW, and the nanoclay-loaded wood polymer nanocomposite (WPNC) showed the highest value than others. The highest increment was found for WPNC (increased by $30.11 \%$ ) followed by WPC (increased by $26.34 \%$ ), WM2 (increased by $24.19 \%$ ), and WM1 (increased by $10.75 \%$ ), respectively. However, the reverse trend (Figure 3(b)) was observed in the case of $Q^{-1}$. The $Q^{-1}$ value of WPC was lower than that of RW and the WPNC exhibited the lowest value. It had been reported that wood with higher value of $E_{d} / \gamma$ and lower in $Q^{-1}$ is suitable for soundboards of violins and guitars $[3,21]$. It is suggested that the chemically impregnated Kayu Malam wood polymer composite (WPC) can be used for making soundboards, and nanoclayincorporated wood polymer nanocomposite (WPNC) is most suitable for this purposes.

On the other hand, the ACE (Figure 3(c)) of WPC and WPNC was slightly lower than RW, whereas the WPC and
WPNC were found with similar ACE values. It can be stated that chemical impregnation has a minor effect on ACE of wood for musical instruments. It is also suggested that the musical instrument made from chemically impregnated Kayu Malam wood polymer composite (WPC) and also wood polymer nanocomposite (WPNC) to be played longer without losing tone quality [7]. The above results are due to enhanced interfacial interaction among the wood cell walls, polymer, and nanoclay into the composite system [18] which is evident from SEM images shown in Figure 4.

3.3. SEM Study. The SEM images of RW, WPC, and WPNC are presented in Figure 4. The figure indicates that there appear significant differences in the interfacial interaction between fiber and polymer matrix in the composite system. The SEM image of RW shows the fiber pullout with rough surfaces and voids (Figure 4(a)). The treated wood polymer composite (WPC) shows better interfacial interaction between wood and polymer matrix (Figure 4(b)) [22].

The improvement of interfacial adhesion between wood and polymer is due to the chemical modification as well as 


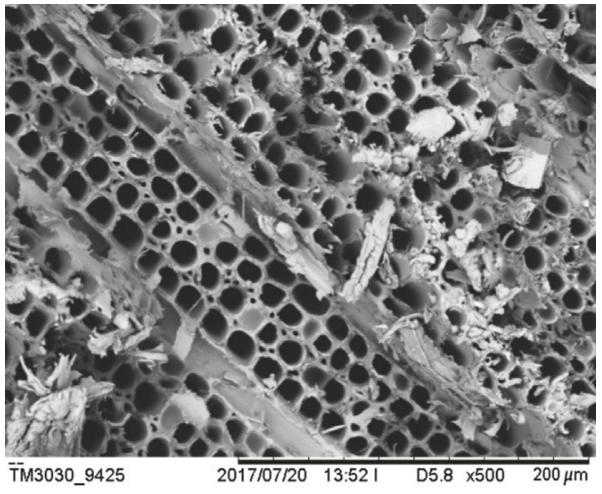

(a)

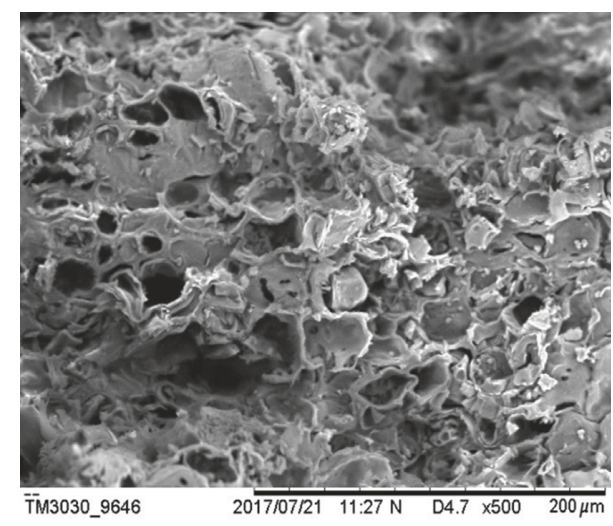

(b)

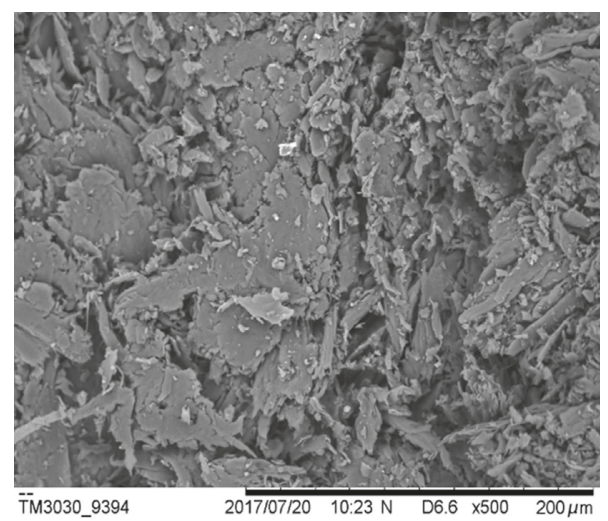

(c)

FIgURE 4: SEM images for RW (a), WPC (b), and WPNC (c).

polymerization that enhanced the hydrophobicity of wood fiber [8]. In addition, the clay-incorporated wood polymer nanocomposite (WPNC) showed less fiber pullout from the fractured surface and better dispersion of filler throughout the matrix which in turn improved interfacial interaction among wood, polymer, and nanoclay (Figure 4(c)). This is due to the MMT particles that increased the interaction between polymer and wood fiber [23]. As a result, a significant improvement in acoustic properties of the nanocomposites indicated that St, VA, and MMT had been successfully impregnated into Kayu Malam wood which is reflected in Figure 3 earlier.

\section{Conclusions}

Nowadays, the wood species are selected for musical instruments by the musical instrument maker due to its remarkable acoustic properties. Individual musical instruments require different acoustic properties for their optimal sound for soundboards, xylophone bars, and violin bows. The hygroscopic nature of wood affects the tone quality of wooden musical instruments. In this study, in order to improve or stabilize the acoustic properties, Kayu Malam wood species was chemically impregnated with styrene, vinyl acetate, and montmorillonite nanoclay through the preparation of wood polymer composites
(WPCs) and wood polymer nanocomposites (WPNCs). The first mode of vibration was considered to evaluate the acoustic properties such as specific dynamic Young's modulus $\left(E_{d} / \gamma\right)$, internal friction $\left(Q^{-1}\right)$, and acoustic converting efficiency (ACE) using the free-free flexural vibration technique. The chemical modification of wood and interfacial interaction among wood, polymer, and nanoclay were confirmed through Fourier transform infrared spectroscopy (FTIR) and scanning electron microscopy (SEM) test analysis.

It was observed that the chemically impregnated wood composite showed a higher value of $E_{d} / \gamma$ than raw wood, and the nanoclay-loaded wood nanocomposite showed the highest value than others. The highest increment was found for WPNC (increased by $30.11 \%$ ) followed by WPC (increased by $26.34 \%$ ), WM2 (increased by $24.19 \%$ ), and WM1 (increased by $10.75 \%$ ), respectively. However, the reverse trend was observed in the case of $Q^{-1}$. On the other hand, the $Q^{-1}$ value of WPC was lower than that of RW and the WPNC exhibited lowest value, and it was seen that the chemical impregnation has a minor effect on ACE of wood for making musical instruments.

The results suggested that the chemically impregnated Kayu Malam wood polymer composite (WPC) and nanocomposite (WPNC) is suitable for making soundboards of violin and guitar instruments to be played longer without losing tone quality. 


\section{Conflicts of Interest}

The authors declare that they have no conflicts of interest regarding the publication of this paper.

\section{Acknowledgments}

The authors acknowledge the financial support provided by the Universiti Malaysia Sarawak (Grant no. F02/DPD/1598/2017) and the Ministry of Higher Education (MOHE), Malaysia, under the Fundamental Research Grant no. FRGS02 (01)/1085/2013(31). The authors are also thankful to Dr. Ismail jusoh, Faculty of Resource Science \& Technology, Universiti Malaysia Sarawak, for identifying the species as wood scientist and proofreading this paper.

\section{References}

[1] H. Yano, M. Norimoto, and R. M. Rowell, "Stabilization of acoustical properties of wooden musical instruments by acetylation," Wood and Fiber Science, vol. 25, no. 4, pp. 395-403, 1993.

[2] Y. Sedik, S. Hamdan, I. Jusoh, and M. Hasan, "Acoustic properties of selected tropical wood species," Journal of Nondestructive Evaluation, vol. 29, no. 1, pp. 38-42, 2010.

[3] S. Hamdan, I. Jusoh, M. R. Rahman, and M. de Juan, "Acoustic properties of Syzygium sp., Dialium sp., Gymnostoma sp., and Sindora sp. wood," BioResources, vol. 11, no. 3, pp. 5941-5948, 2016.

[4] W. L. James, "Vibration, static strength and elastic properties of clear douglas fir at various levels of moisture content," Forest Products Journal, vol. 14, no. 9, pp. 409-413, 1964.

[5] T. Sasaki, M. Noromoto, T. Yamada, and R. M. Rowell, "Effect of moisture on the acoustical properties of wood," Japan Wood Research Society, vol. 34, no. 10, pp. 794-803, 1988.

[6] J. C. Schelleng, "Acoustical effects of violin varnish," Journal of Acoustic Society of America, vol. 44, no. 5, pp. 1175-1183, 1968.

[7] R. M. Rowell, "Acoustical properties of acetylated wood," Journal of Chemistry and Chemical Engineering, vol. 7, no. 9, pp. 834-841, 2013.

[8] M. S. Islam, S. Hamdan, A. Hassan, Z. A. Talib, and H. R. Sobuz, "The chemical modification of tropical wood polymer composites," Journal Composite Materials, vol. 48, no. 7, pp. 783-789, 2014.

[9] M. R. Rahman, S. Hamdan, M. Hasan, R. Baini, and A. S. Ahmed, "Physical, mechanical, and thermal properties of wood flour reinforced maleic anhydride grafted unsaturated polyester (UP) biocomposites," BioResources, vol. 10, no. 3, pp. 4557-4568, 2015.

[10] L. Fang, X. Xiong, X. Wang, H. Chen, and X. Mo, "Effects of surface modification methods on mechanical and interfacial properties of high-density polyethylene-bonded wood veneer composites," Journal of Wood Science, vol. 63, no. 1, pp. 65-73, 2017.

[11] S. Hamdan, H. A. Wahid, I. A. Musoddiq, and Y. Nyawai, "Marimba instrument construction from Kayu Malam wood (Diospyros maingayi)," BioResources, vol. 13, no. 1, pp. 43-52, 2018.

[12] M. G. S. Yap, L. H. L. Chia, and S. H. Teoh, "Wood polymer composites from some tropical hardwoods," Journal of Wood Chemistry and Technology, vol. 10, no. 1, pp. 1-19, 1990.
[13] A. Hazarika, R. R. Devi, and T. K. Maji, "Studies on properties of softwood (Ficus hispida)/PMMA nanocomposites reinforced with polymerizable surfactant-modified nanoclay," Polymer Bulletin, vol. 68, no. 7, pp. 1989-2008, 2012.

[14] M. Gecer, E. Baysal, and H. Toker, "The effect of boron compounds impregnation on physical and mechanical properties of wood polymer composites," Wood Research, vol. 60, no. 5, pp. 723-738, 2015.

[15] Y. F. Li, Y. X. Liu, X. M. Wang, Q. L. Wu, H. P. Yu, and J. Li, "Wood-polymer composites prepared by the in-situ polymerization of monomers within wood," Journal of Applied Polymer Science, vol. 119, no. 6, pp. 3207-3216, 2011.

[16] X. Yu, D. Sun, and X. Li, "Preparation and characterization of urea-formaldehyde resin-sodium montmorillonite intercalationmodified poplar," Journal of Wood Science, vol. 57, no. 6, pp. 501-506, 2011.

[17] X. Han, Q. Zhang, R. Li, and J. Pu, "Grafting organicinorganic compound modifier onto wood cell walls for enhanced mechanical strength in wood composites," Wood Research, vol. 62, no. 2, pp. 197-210, 2017.

[18] R. R. Devi and T. K. Maji, "Chemical modification of simul wood with styrene-acrylonitrile copolymer and organically modified nanoclay," Wood Science and Technology, vol. 46, no. 1-3, pp. 299-315, 2012.

[19] T. Ono and M. Norimoto, "On physical criteria for the selection of wood for soundboards of musical instruments," Rheologica Acta, vol. 23, no. 6, pp. 652-656, 1984.

[20] H. Akitsu, M. Norimoto, T. Morooka, and R. W. Rowell, "Effect of humidity on vibrational properties of chemically modified wood," Wood and Fiber Science, vol. 25, no. 3, pp. 250-260, 1993.

[21] M. Matsunaga, M. Sugiyama, K. Minato, and M. Norimoto, "Physical and mechanical properties required for violin bow materials," Holzforschung, vol. 50, no. 6, pp. 511-517, 1996.

[22] Y. Li, D. Gong, X. Dong, and Z. Liu, "Mechanical properties of wood-polymer composite prepared by in-situ polymerization of methyl methacryalte and styrene," Applied Mechanics and Materials, vol. 166-169, pp. 2938-2941, 2012.

[23] M. T. Sultan, M. R. Rahman, S. Hamdan, J. C. H. Lai, and Z. A. Talib, "Clay dispersed styrene-co-glycidyl methacrylate impregnated Kumpang wood polymer nanocomposites: impact on mechanical and morphological properties," BioResources, vol. 11, no. 3, pp. 6649-6662, 2016. 


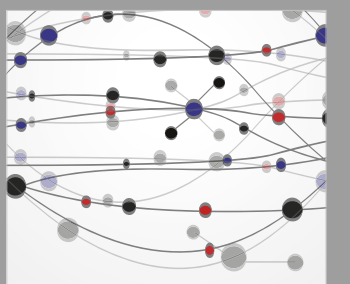

The Scientific World Journal
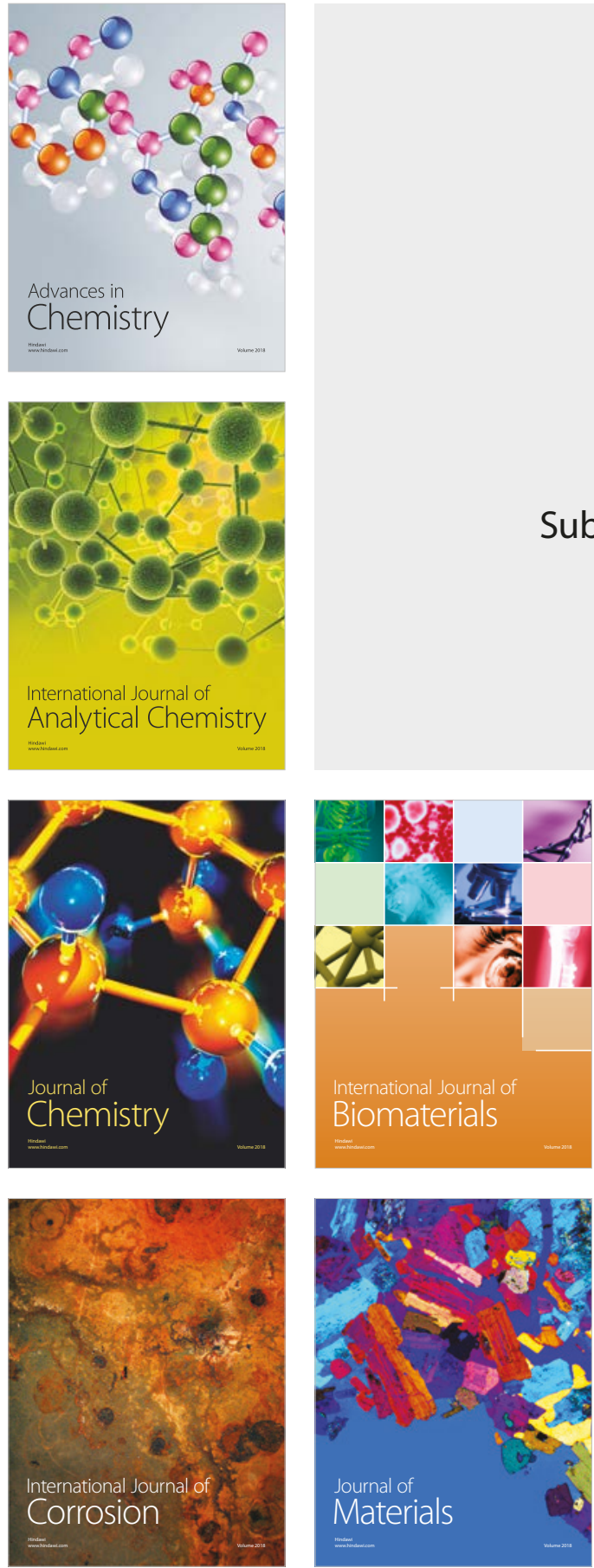

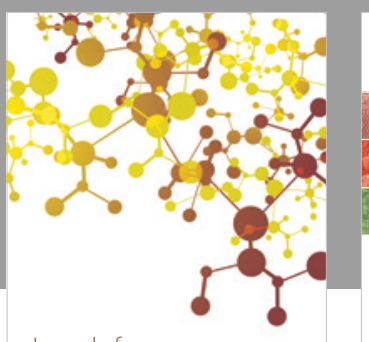

Journal of

Applied Chemistry
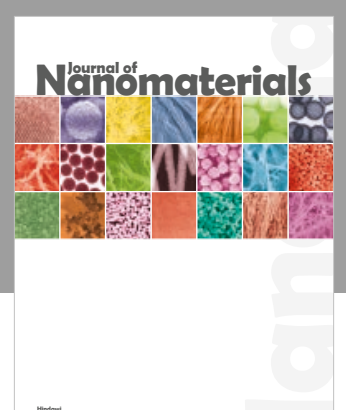

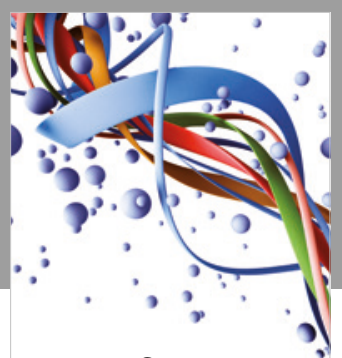

Scientifica

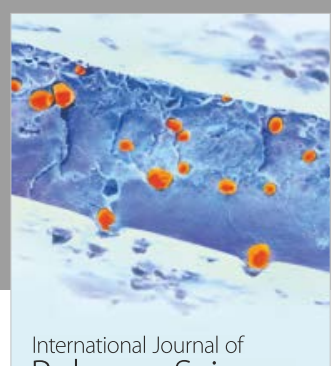

Polymer Science

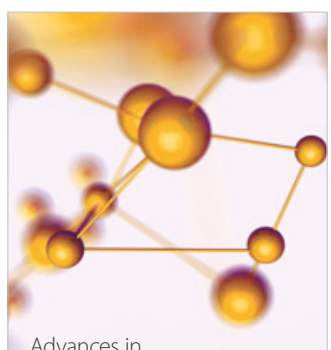

Physical Chemistry
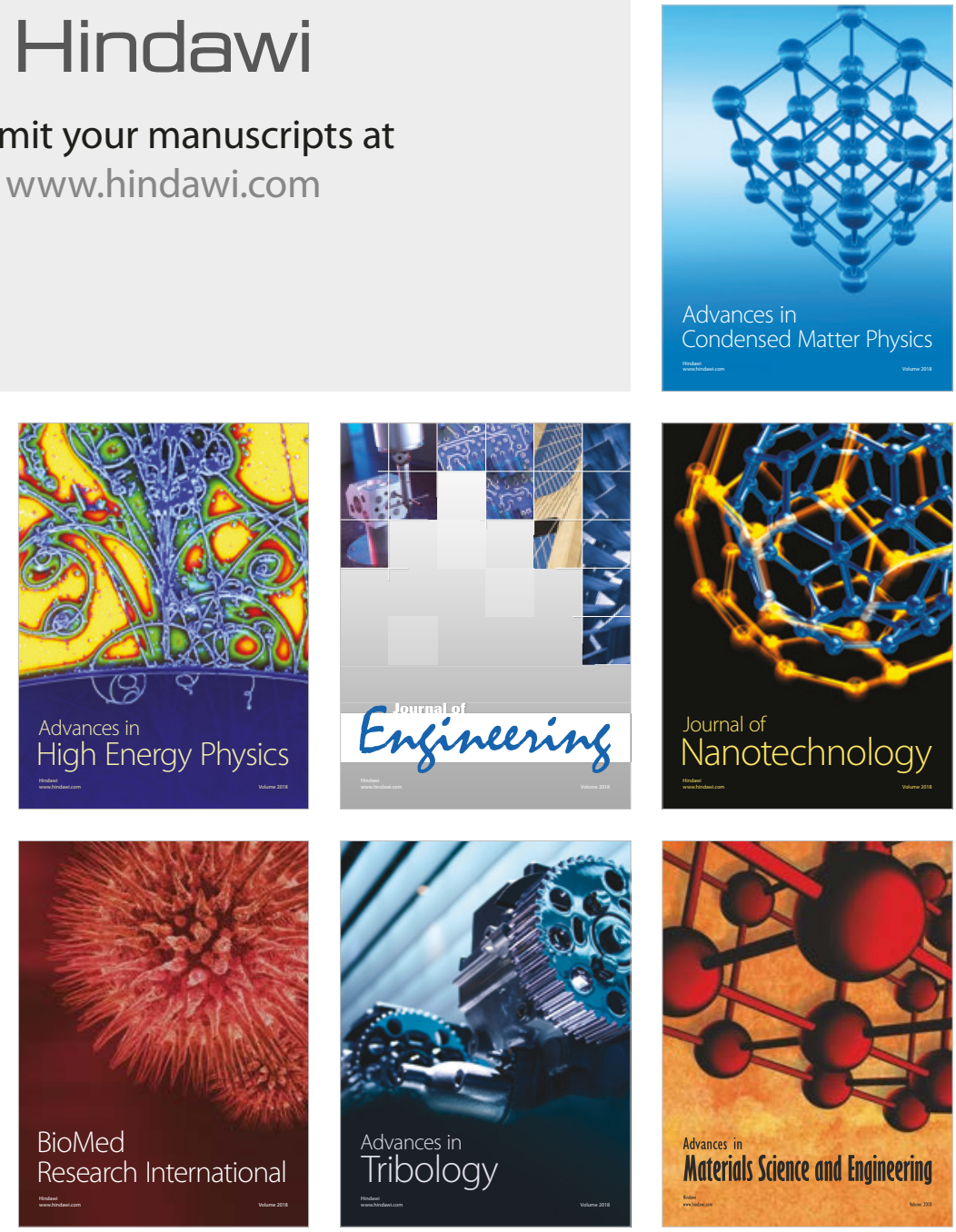